О.Ю. Нечитайло, В.М. Коновчук

\title{
ДІАГНОСТИЧНА ЦІННІСТЬ ІНФРАЧЕРВОНОЇ ТЕРМОМЕТРІЇ У ХВОРИХ НА ЦУКРОВИЙ ДІАБЕТ ІЗ МАНІФЕСТНИМИ АНГІОПАТІЯМИ НІГ
}

Вищий державний навчальний заклад України «Буковинський державний медичний університет», м. Чернівці

Резюме. У статті вивчено можливості застосування інфрачервоної термометрії для складання карти температур у 16 хворих на цукровий діабет із хірургічними ускладненнями 3 боку нижніх кінцівок. Встановлено температурний градієнт кінцівок, відмічено значне

Вступ. Цукровий діабет (ЦД) надалі залишається однією з важливих проблем охорони здоров'я через ураження багатьох органів і тканин [1, 3]. ЦД відрізняється значною кількістю ускладнень, в основі яких лежать генералізовані ангіопатії та порушення мікроциркуляції в різних органах. Одним із найбільш тяжких хірургічних ускладнень є синдром діабетичної стопи (СДС) $[2,5]$, який трапляється у 8,3-25 \% пацієнтів із ЦД. Відсутність симптомів на ранньому етапі формування СДС створює складнощі своєчасної діагностики у пацієнтів із ЦД.

Останнім часом все ширше використовується аналіз локальної температури окремих частин тіла, як комплексний показник стану мікроциркуляції та інтенсивності метаболічних процесів [4, 7]. Висока чутливість, низька вартість, швидкість і простота виконання та повна безпечність локальної термометрії роблять цей метод доступним та незамінним у діагностиці і моніторингу ефективності лікування цілого ряду патологічних процесів $[7,8,10]$. Із сучасних методів дослідження локальної температури найчастіше використовують інфрачервону термометрію, термографію, радіотермометрію, теплобачення та інші. Не зважаючи на стабільну температуру ядра людського тіла, як пойкілотермної істоти, різні ділянки шкіри фізіологічно мають різну температуру, із найбільшим зниженням на дистальних відрізках. Патологічне зниження локальної температури найчастіше пов'язано з порушеннями мікроциркуляції, метаболічними та дегенеративними змінами у тканинах, розладами соматичної іннервації [9]. Основними причинами підвищення локальної температури є запальні процеси, із розширенням судин та інтенсифікацією обмінних процесів, злоякісні новоутворення, ендокринні та нейрорегуляторні розлади $[4,6,7]$. Зміни температури випереджають інші клінічні прояви, що дуже важливо для ранньої діагностики і своєчасного початку лікування [4]. При ЦД зміни локальної температури вивчені недостатньо, хоча в ряді робіт вказується на діагностичне значення співвідношення між загальною та місцевою температурою в підошовній ділянці діабетичної стопи при виразках кінцівки $[6,10]$.

Мета дослідження. Вивчити особливості та діагностичну цінність інфрачервоної термометрії (C) О.Ю. Нечитайло, В.М. Коновчук, 2016 зниження локальної температури в пацієнтів із клінічними проявами ангіопатій та загрозою розвитку діабетичної стопи.

Ключові слова: цукровий діабет, ангіопатії, діабетична стопа, інфрачервона термометрія.

у пацієнтів із ЦД із хірургічними ускладненнями з боку нижніх кінцівок.

Матеріал і методи. Під спостереженням перебувало 16 хворих (12 чоловіків і 4 жінки) віком від 46 до 82 років (у середньому 64,2 $\pm 2,8$ року) із ЦД 2-го типу з маніфестними ангіопатіями нижніх кінцівок, які були госпіталізовані 3 приводу хірургічних ускладнень основного захворювання. Всі пацієнти комплексно обстежені (мікросоціологічне анкетування та клінічнолабораторне й інструментальне обстеження). Для оцінки надлишкової маси тіла в пацієнта розраховували індекс маси тіла (IMT). Локальну термометрію проводили інфрачервоним пірометром DT-8836 (сертифікований за європейським стандартом EU 60601-1-2:2007, фірма RoHS, Німеччина). Вимірювання проводили перпендикулярно до обстежуваної ділянки на відстані 10 см (діапазон - 5-15 см). Інфрачервона термометрія проводилась в усіх пацієнтів у ранкові години після їх 15-хвилинної акліматизації до термонейтральної температури кімнати $\left(23 \pm 2,0^{\circ} \mathrm{C}\right)$, у стандартному одязі, у стані спокою. Кожне обстеження включало три вимірювання 3 розрахунком середнього значення. Абсолютні локальні показники переводилися у відносні шляхом ділення на показник загальної температури тіла і порівнювалися між собою в динаміці лікування. За базальну температуру тіла $\left(\mathrm{t}_{0}\right)$ бралося вимірювання, яке проводилося над проекцією сонної артерії при повороті голови в бік вимірювання, над точкою пульсації артерії. Вираховувалася різниця температури у різних ділянках - $\mathrm{DT}^{\mathrm{o}}$ у \% до базального показника. Отримані результати оброблялися статистично (обрахунок та порівняння середніх, показників кореляції) із використанням програми Statistica 6,0 (StatSoft).

Результати дослідження та їх обговорення. Тривалість ЦД у пацієнтів коливалася від 3 до 15 років (у середньому $8,9 \pm 1,8$ року), причому 31,2 \% мали тривалість хвороби більше 10 років. Середньотяжка форма хвороби була в семи осіб $(43,8)$, тяжкий перебіг - у 9 пацієнтів $(56,2 \%)$. Більшість осіб (8 пацієнтів - 50 \%) отримували терапію пероральними цукрознижувальними препаратами, останнім часом п'ять пацієнтів $(31,2 \%)$ переведені на інсулін чи комбіновану терапію, три пацієнти взагалі не отримували медикаменто- 


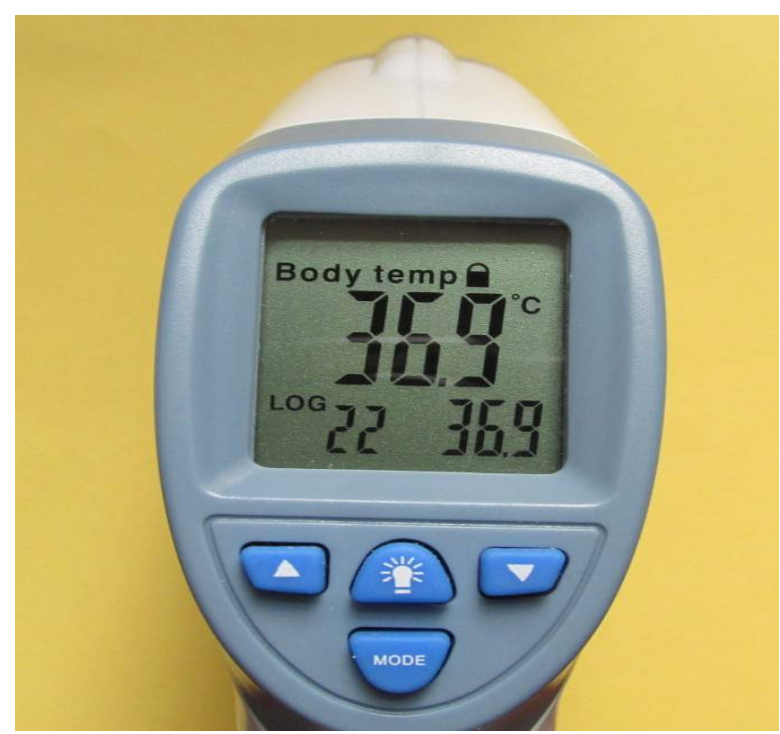

Рис. 1. Екран пірометра 3 даними останнього вимірювання та середньою величиною трьох останніх показників

зних засобів для лікування ЦД. Хоча спеціальної дієти дотримувалася більша частина обстежених пацієнтів, втім 37,5 \% не застосовували ніяких обмежень у харчуванні, а в чотирьох осіб мало місце зловживання алкоголем. Серед ускладнень ЦД були порушення зору різного ступеня (11 осіб - 68,8 \%), ураження нирок та нижніх кінцівок (по чотири особи - $25 \%$ ). Надлишкова маса тіла вважається одним із чинників розвитку захворювань серцево-судинної системи, артеріальної гіпертензії, особливо в поєднанні із ЦД, а також фактором ризику виникнення періопераційних ускладнень. Тільки п'ять пацієнтів (31,2 \%) мали нормальні показники IMT, дев'ять осіб (56,2 \%) - мали надлишкову масу тіла і у двох було ожиріння, а середній показник IMT по

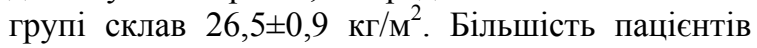
$(68,5 \%)$ мала підвищений артеріальний тиск: середня величина систолічного тиску склала 14$0,3 \pm 4,6$ мм $\mathrm{Hg}$, діастолічного - 87,8 $\pm 3,5$ мм $\mathrm{Hg}$. Рівень цукру крові при госпіталізації був у межах від 4 до 21 ммоль/л, середній показник у обсте-

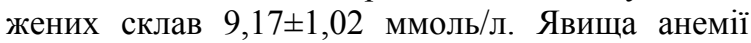
були в чотирьох пацієнтів. Окремо в пацієнтів уточнювалася їх температурна толерантність: температура комфорту в приміщенні вище $22^{\circ} \mathrm{C}$ була бажаною для 13 пацієнтів $(81,2 \%)$, на підвищену чутливість до холоду вказували шість осіб $(37,5 \%)$, на тяжку переносимість спеки - 8 (50\%).

Під час обстеження температура в приміщенні в зоні ліжка пацієнта в середньому була в термонейтральній зоні $-23,9 \pm 0,37^{\circ} \mathrm{C} \quad(21,4-$ $\left.25,0^{\circ} \mathrm{C}\right)$. Вимірювання температури на різних ділянках тіла проводилось 3 однакової відстані тричі 3 проміжком у 2-3 хвилини, тільки у 5 \% випадків спостерігалася різниця між вимірювань у межах $0,1^{\circ} \mathrm{C}$, що вказує на надійність методу інфрачервоної термометрії. Середній показник трьох останніх вимірювань автоматично розраховувався приладом (рис. 1).

Результати вимірювань наведені в таблиці 1. Градієнт температури між точкою 3 найвищим показником та найнижчим склав $4,6^{\circ} \mathrm{C}$. Наші дані мало різняться від результатів дослідження J. J. van Netten [8], в якому температура стопи хворих на діабет знаходилась у межах $29^{\circ}-33^{\circ} \mathrm{C}$.

Середній градієнт температури на нижніх кінцівках наведено на рис. 2. Температура в паховій ділянці мало відрізняється від базальної, але в дистальних відділах різниця температур зростала.

Асиметрія розподілу температури поверхні шкіри спостерігалася як на лівій та правій кінцівці, так і в межах ангіосом однієї стопи. Так, у пацієнта 82 років відмічена найбільша різниця між стопами - градієнт температури на тильній частині лівої стопи становив $20,5 \%$, у той час як на правій він був всього 6,0\%, а на підошві відповідно - 31,0 \% та 9,0\%. У нашій групі паціснтів із значною різницею температури було вісім, крім того в одного з обстежених, з ампутованою правою стопою, на лівій нозі градієнт у нижніх відділах був близько 30 \%, 3 клінічною загрозою виникнення некрозу пальців. У межах однієї стопи в чотирьох пацієнтів спостерігалася майже двократна різниця між ангіосомами, частіше страждала латеральна частина стопи.

Виникнення ангіопатій кінцівок призводило до зменшення інтенсивності кровотоку, зниження метаболічної активності тканин та, відповідно,

Показники шкірної температури на різних ділянках тіла

Таблиця 1

\begin{tabular}{|c|c|c|c|c|c|c|c|}
\hline \multirow{2}{*}{$\begin{array}{c}\text { № } \\
\text { ח/п }\end{array}$} & \multirow{2}{*}{ Точка вимірювання } & \multicolumn{5}{|c|}{ Температура, ${ }^{\circ} \mathrm{C}$} \\
\cline { 3 - 8 } & & \multicolumn{3}{|c|}{ Ліва половина } & \multicolumn{3}{|c|}{ Права половина } \\
\cline { 3 - 8 } & & $\mathrm{M}$ & $\mathrm{m}$ & діапазон & $\mathrm{M}$ & $\mathrm{m}$ & діапазон \\
\hline 1 & Над сонною артерією & 34,8 & 0,26 & $32,0-36,5$ & 34,7 & 0,25 & $32,3-36,1$ \\
\hline 2 & Підпахвова ділянка & 34,7 & 0,33 & $32,2-37,4$ & 34,9 & 0,38 & $33,3-37,5$ \\
\hline 3 & Ліктьова ділянка & 33,7 & 0,21 & $32,0-35,5$ & 33,6 & 0,30 & $30,0-35,1$ \\
\hline 4 & Долоня & 33,4 & 0,35 & $30,9-36,1$ & 34,0 & 0,30 & $31,6-36,4$ \\
\hline 5 & Пахова складка & 34,8 & 0,38 & $31,5-36,9$ & 34,6 & 0,35 & $31,8-36,7$ \\
\hline 6 & Підколінна зона & 33,3 & 0,27 & $31,7-35,4$ & 33,6 & 0,30 & $31,7-35,5$ \\
\hline 7 & Тильний бік стопи & 30,6 & 0,73 & $25,5-33,6$ & 31,1 & 0,62 & $26,2-34,4$ \\
\hline 8 & Підошва & 30,2 & 0,79 & $24,6-33,7$ & 29,9 & 0,75 & $25,7-34,3$ \\
\hline
\end{tabular}




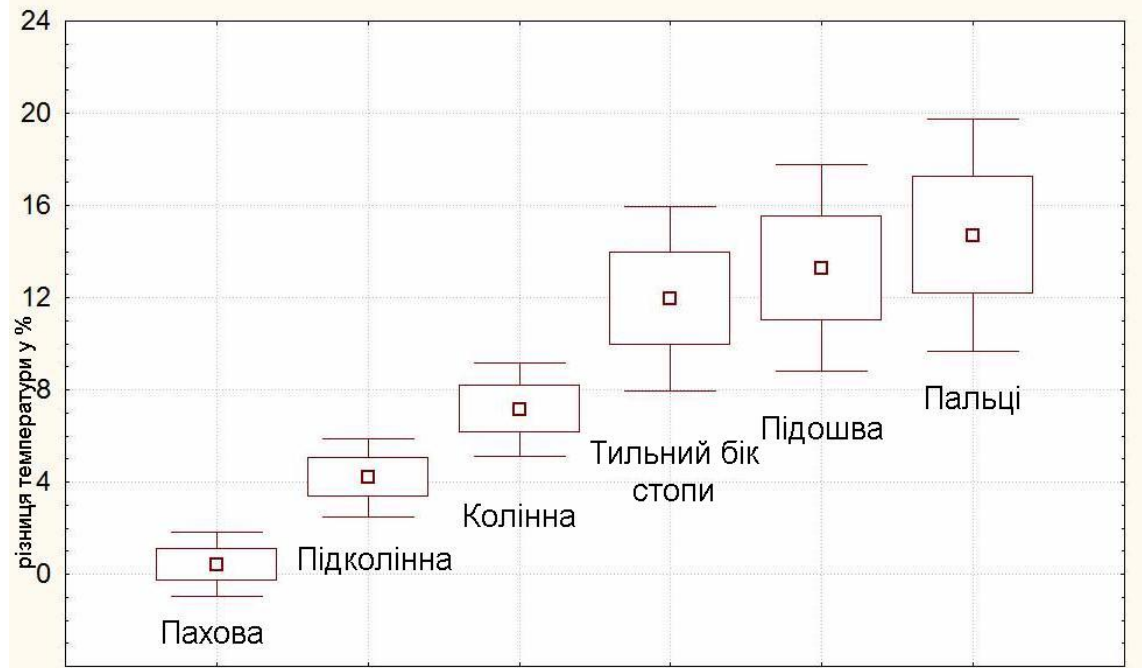

Ділянка нижньої кінцівки

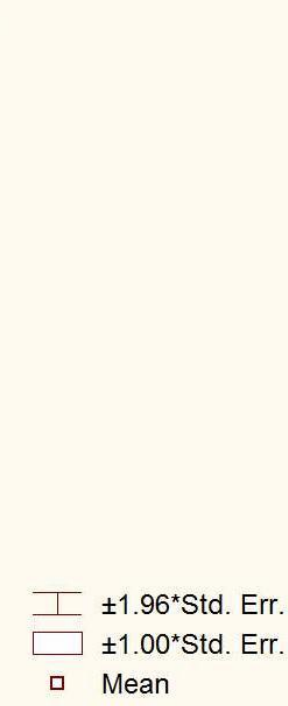

Mean

Рис. 2. Різниця температури (до базальної - $\mathrm{DT}^{\mathrm{o}}$, у \%) на різних ділянках нижньої кінцівки

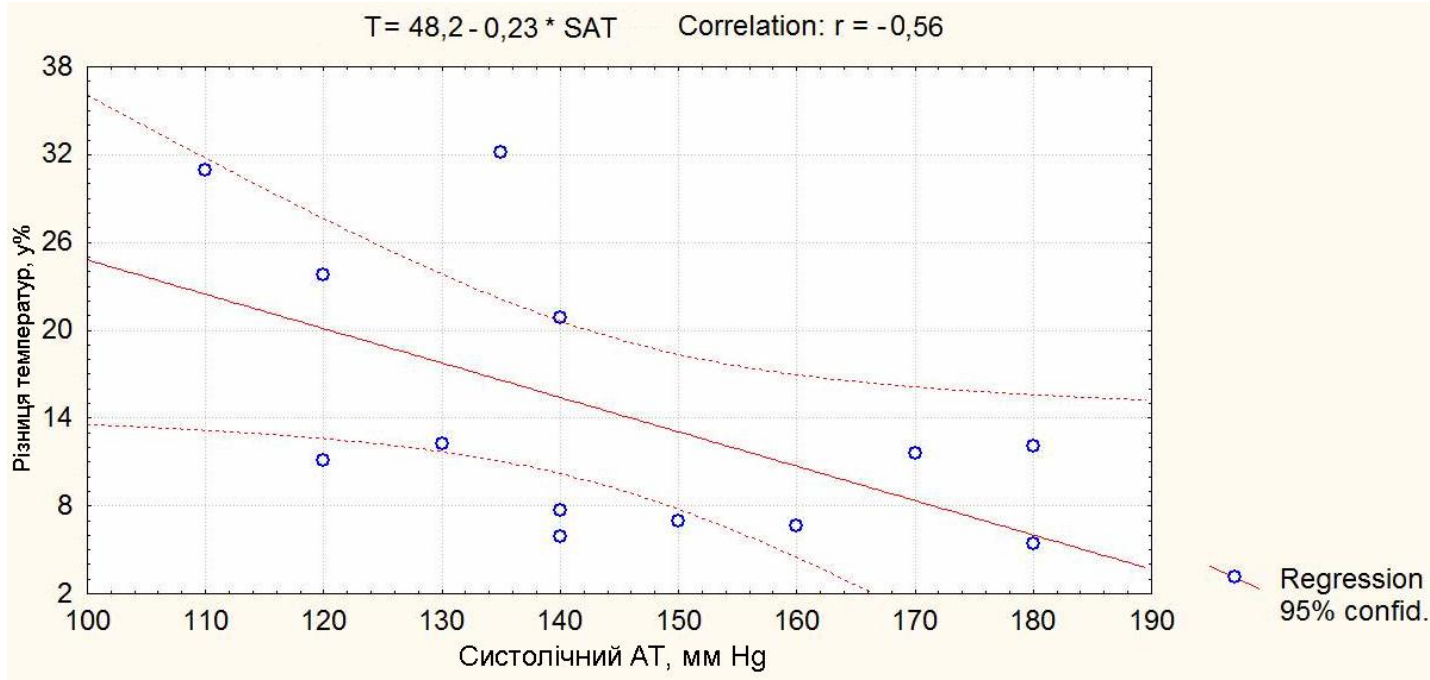

Рис. 3. Регресійна модель зв'язку між артеріальним тиском та градієнтом температури дистальних відділів нижніх кінцівок

до більш низької температури дистальних ділянок ніг. Організм реагував на це підвищенням артеріального тиску. Відмічена вірогідна кореляція між систолічним АТ та температурою пальців ніг $(\mathrm{r}=-0,56, \mathrm{p}<0,05)$ (рис. 3).

Ми не знайшли вірогідних кореляцій з тривалістю хвороби та характером протидіабетичного лікування. Порушення температури кінцівок часто асоціювало з ураженням судин очного дна $(\mathrm{r}=0,36, \mathrm{p}<0,05)$, зменшенням концентраційної функції нирок $(\mathrm{r}=0,76, \mathrm{p}<0,05)$. Менший градієнт температур корелював зі здоровим способом життя $(\mathrm{r}=-0,54, \mathrm{p}<0,05)$, дотриманням правил дієтичного харчування $(\mathrm{r}=-0,56, \mathrm{p}<0,05)$, достатньою фізичною активністю $(\mathrm{r}=-0,59, \mathrm{p}<0,05)$.

Ми визначали надійність методики інфрачервоної термометрії тільки у трьох пацієнтів у вигляді ретесту, в якому отримані результати повністю збігалися з даними першого обстеження. Саме на високу надійність цього виду локальної термометрії вказують і бразильські науковці (L. F. Balbinot et al., 2013) [11].

\section{Висновок}

Таким чином, інфрачервона термометрія $\epsilon$ доступним та чутливим методом ранньої діагностики порушень кровообігу нижніх кінцівок та виявлення ризику формування тяжких форм діабетичної стопи. Критерієм такого ризику можна вважати градієнт температури більше 10\%.

Перспективи подальших досліджень. Перспективними при подальших дослідженнях є вивчення локальних температурних реакцій на проведення функціональних проб, аналіз взаємозв'язків між температурою та станом мікроциркуляції, вивчення ролі різних патогенетичних факторів у розвитку хірургічних ускладнень хворих на цукровий діабет.

\section{Література}

1. Демина Т.В. Сахарный диабет, летальность, факторы риска и нозологический профиль у больных отделения интенсивной терапии / Т.В. Демина // Пит. експерим. клін. мед. - 2004. - Т. 1, № 8. - С. 102-107.

2. Колотило О.Б. Значення чинників ризику для оцінки прогнозу хворих на синдром діабетичної стопи / О.Б. Колотило // Бук. мед. вісник. - 2008. - Т. 12, № 1. - C. 90-96. 
3. Паньків І.В. Особливості гемодинамічних показників у хворих на артеріальну гіпертонію і цукровий діабет 2-го типу / І.В. Паньків // Бук. мед. вісник. - 2010. Т. 14, № 4. - С. 75-79.

4. Потехина Ю.П. Причины изменения локальной температуры тела / Ю.П. Потехина, М.В. Голованова // Мед. альманах. - 2010. - № 2 (11). - С. 297-298.

5. Gale L. Patients' perspectives on foot complications in type 2 diabetes: a qualitative study / L. Gale, K. Vedhara, A. Searle // Br. J. Gen. Pract. - 2008. - Vol. 58, № 553. P. 555-563.

6. Houghton V.J. Is an increase in skin temperature predictive of neuropathic foot ulceration in people with diabetes? A systematic review and meta-analysis / V.J. Houghton, V.M. Bower, D.C. Chant // J. Foot Ankle Res. 2013. - Vol. 6. - P. 31.

7. Infrared thermography for temperature measurement and non-destructive testing / R. Usamentiaga, P. Venegas, J. Guerediaga [et al.] // Sensors (Basel). - 2014. - Vol. 14 (7). - P. 12305-12348.
8. Infrared thermal imaging for automated detection of diabetic foot complications / J.J. van Netten, J.G. van Baal, C. Liu [et al.] // J. Diabetes Sci. Technol. - 2013. - Vol. 7 (5). - P. 1122-1129.

9. Morphological pattern classification system for plantar thermography of patients with diabetes / T. Mori, T. Nagase, K. Takehara [et al.] // J. Diabetes Sci. Technol. 2013. - Vol. 7 (5). - P. 1102-1112.

10. Quantitative estimation of temperature variations in plantar angiosomes: a study case for diabetic foot / H. Peregrina-Barreto, L. A. Morales-Hernandez, J. J. RangelMagdaleno [et al.] // Comput. Math. Methods Med. 2014. - Vol. 2014. - P. 585306.

11. Repeatability of infrared plantar thermography in diabetes patients: a pilot study / L.F. Balbinot, C.C. Robinson, M. Achaval [et al.] // J. Diabetes Sci. Technol. - 2013. Vol. 7 (5). - P. 1130-1137.

\section{ДИАГНОСТИЧЕСКАЯ ЦЕННОСТЬ ИНФРАКРАСНОЙ ТЕРМОМЕТРИИ У БОЛЬНЫХ САХАРНЫМ ДИАБЕТОМ С МАНИФЕСТНЫМИ АНГИОПАТИЯМИ НОГ}

\section{Е.Ю. Нечитайло, В.Н. Коновчук}

Резюме. В статье изучены возможности применения инфракрасной термометрии для составления карты температур у 16 больных сахарным диабетом с хирургическими осложнениями со стороны нижних конечностей. Установлен температурный градиент конечностей, отмечено значительное снижение локальной температуры у пациентов с клиническими проявлениями ангиопатий и угрозой развития диабетической стопы.

Ключевые слова: сахарный диабет, ангиопатии, диабетическая стопа, инфракрасная термометрия.

\section{DIAGNOSTIC VALUE OF INFRARED THERMOMETRY IN DIABETIC PATIENTS WITH MANIFESTAL FOOT ANGIOPATHIE}

\section{O.Y. Nechytaylo, V.M. Konovchuk}

Abstract. The article studies the possibility of using infrared thermometry for temperature mapping in 16 diabetic patients with surgical complications of the lower extremities. The temperature gradient of the limbs and a significant reduction of local temperature in patients with clinical manifestations of angiopathy and the risk of diabetic foot were established.

Key words: diabetes, angiopathy, diabetic foot, infrared thermometry.

Higher State Educational Institution of Ukraine «Bukovinian State Medical University» (Chernivtsi)

Рецензент - проф. Ю.С. Роговий
Buk. Med. Herald. - 2016. - Vol. 20, № 2 (78). - P. 101-104

Надійшла до редакції 19.02.2016 року

(C) О.Ю. Нечитайло, В.М. Коновчук, 2016 